\title{
Translation of vulgarism in Mass media
}

\author{
Ludmila Meskova
}

\section{DOI: 10.18355/XL.2017.10.03.08}

\begin{abstract}
We have observed more vulgarisms in mass media recently. This phenomenon is typical for TV, social networks, the Internet, radio, advertising, and so on. This study is focused on the translation of vulgarisms in the dialogue of French TV series into Slovak (target language), and their analysis. We analyse also the translations of students studying translation. The results of our research show that the degree of the perception of vulgarity in some lexical units, either words or phrasemes, is not the same in the compared languages. We noticed that the translation of some vulgar expressions caused many problems for students due to the lack of knowledge or experience. University teachers should teach future translators that language norm should be respected. Translators can lessen the level of vulgarity and intercultural aspect should be taken into consideration. The work of the translator is significant. On one hand, translators can shift the dialogue text to a more intensive level of vulgarity, and on the other they can soften vulgar expressions.
\end{abstract}

Key words: Translation, mass media, vulgarisms, dialogue of TV series, intercultural aspect

\section{Introduction}

More and more vulgarisms are currently occurring in mass media. This phenomenon is typical of the dialogue in dubbed movies, the Internet, social networks, billboards, radio (songs, the culture of the language of commentators in some radio stations, and so on). Our long experience with teaching translation and the students of translations studies - future translators as well as our experience of the Slovak TV translator (public institution) spurred us on to deliberate seriously on this issue of the translation of vulgar lexis (words, phrasemes, slang - at the colloquial and slang level of language). We focused on the dialogue of television films. We discovered that what is vulgar in the source language is not necessarily vulgar in the target language and vice versa. Furthermore, the degree of the perception of vulgarity in some lexical units, either words or phrasemes, is not the same in the compared languages.

\section{Translation and Mass Media}

There are many definitions of translation. P. Mogorrón Huerta (2012: 10, 83) claims that translation is the production of the contents of a discourse in a target language, which are first expressed in a source language. This requires a certain number of anticipatory steps to avoid possible losses at two levels: formal and conceptual. A translator cannot be satisfied with simple comparative linguistic structures, but they must also take into account cultural, rhetoric, stylistic and other contexts which should be reflected in the target language. E. Gromová - D. Müglová (2005: 81) are very critical about the development of translation in Slovakia in recent years, and they conclude that translation has become a commercial issue as well as a product for sale. We agree with this fact. This phenomenon not only relates to translations for mass media, but also literary translation and the translation of children's literature. After 1989 (transition to a market-based economy), we could even see the translations of books for children and youth without the names of authors and of course, the names of translators were missing, too. The commercial development of translation can be 
explained and justified by the political, economic and social changes after the fall of the Berlin Wall. It results from the commercialisation of mass media. The programmes are the subject of various influences, even some demagogy. Currently mass media tolerates vulgarisms to a larger extent. It is manifested by the lyrics of songs or the dialogue of television films and series. D. François-Geiger (1991: 8) mentions that le parler branché, (trendy Speech) - argot, are present in all the segments of the population through mass media. This explains a high occurrence of synonyms.

When analysing the translations of French television films, we have noticed that translators do not devote much attention to the meaning of a vulgar expression. They do not translate them correctly, which means that the translation equivalents in the target language do not correspond with the meaning of the original vulgarisms. Translators do not get the accurate degree of the vulgarism. As mentioned above, it is very important to know the meaning of vulgarisms in the source language, to know the nuances of individual meanings, to identify them in context and to find relevant equivalents in target language. It should be emphasised that translators must know a wide range of synonyms in the vulgar lexical units. The question then arises whether a translator is interested in how the public perceives the vulgarisms used in the translations of dubbed television films. In other words, are the vulgar expressions of television figures imposed on the public? It is highly probable that this situation in other countries is similar to that on Slovak TV. According to E. Cohen (2013), French TV should not use some vulgar words. What we see is that the standard language is not respected and the use of a vulgarism exceeds the permissible boundary. Language is rich in relevant synonyms, but unfortunately they are not adequately used. There is an increasing trend to transfer vulgarisms from one culture to the other without taking into account their real meanings. The use of vulgarisms relates to the behaviour of their users. The behaviour not only of the young generation, but also the older one is often arrogant, which is manifested by their speech. The common communication of individuals is significantly influenced by age, education, occupation, social environment, and so on. It is typical of heterogeneity the presence of an oral and written form. The impact of mass media and digital technology is evidential. The communication of youth is more and more free and more expressive (V. Patráš, 2010: 143; 2012: 175). It is not possible to separate vulgarisms, the argot from the environment where they are used. C. Laplace, M. Lederer \& D. Gile (2009) state that the real knowledge of the translator also includes the thematic knowledge of a relevant sphere and topic, the knowledge of a relevant communication situation, social values and norms in socio-cultural groups where a source-language speaker and recipient of the target language belong. Communication among women can be perceived as more vulgar compared to the same communication of men. The same is applicable to a specific group of people for which vulgarisms lose their intensity; i.e. not have such a vulgar impact. The degree of the vulgarity of some expressions is not the same. B. Hochel (1988: 183) considers context, situation and the user of the language the modifiers of vulgarity.

\section{Problems of the Translation of Vulgarisms}

The influence of the lexical language means of a source language on a translator is significant. Specifically, with respect to the translation of the dialogue of television films a translator can be convinced that it is necessary to use the same style and the same vulgarisms in a target language. However, this strategy is not correct. The translator makes mistakes because they translate the vulgarism without taking into account their real meaning in the relevant context. Such a procedure proves the unprofessional approach of the translator. In our opinion, the frequent use of the same vulgarism in one film causes problems for translators. This phenomenon can be seen 
not only in French films, but also in films with English as a source language. According to J. Cohen (2011) the main problem of American films is the frequent use of the word fuck. There are also words formed with the help of lexical elements such as fuck and fucking. According to this author the problem is that it is not possible to translate these words with one word, because their meanings are numerous. In one of Woody Allen's films the word fuck occurs as many as 97 times. The high frequency of this word is striking.

There is the same problem in French with the vulgar words putain or merde. How to find the most suitable equivalent, which solutions the most appropriate for a given situation and context? The opinion of foreign tourists in France regarding the vulgarism putain is very interesting. According to some foreigners the only magic word a foreigner should know travelling to France is the word putain. The first meaning is prostitute. Therefore, foreigners think that they can use it in $99.5 \%$ of common situations such as when you are lost, if you see a beautiful girl, you are hungry or even if you need to go to the toilet. The list of similar situations could be much longer.

The French film Les beaux mecs, transmitted by Slovak TV (the second television programme) is a good example for pointing out that the word putain is excessively used (34 times in one part, Part 2 lasting 48 minutes). We illustrate this with the example of the dialogue between two killers. A TV news anchor is reporting about a shooting at the centre of Paris.

Example No.1:

Kenz : Moi aussi j'aimerais bien passer à la télé comme toi là. Putain! Eh même pas ils parlent de moi, ils sont sérieux là... hein?Même pas, ils parlent de moi là, comme si j'existais même pas! Putain.

Présent.TV: ... permet de penser qu'il a été la cible d'un règlement de compte. Voilà donc

pour l'infor...

Kenz: Eh t' sais quoi j' vais allez les voir moi! Moi j' vais leur dire. Putain éteins moi cette vieille télé d' merde! Putain! J'vais aller les voir, moi, j' vais leur dire tu vas voir. J' vais leur dire qu' t'es ici, qu' t'es avec moi et tu vas voir si je vais pas passer à la télé...

Oh! Oh qu'est-ce qui t'arrive là?Putain qu'est-ce qui m' fout celui là, putain?!

Translatology students or inexperienced translators tend to use a vulgar equivalent, the first meaning of the word putain = prostitute. While translating into Slovak they choose the equivalent kurva, which is a vulgar expression. They do not know all the meanings of this French word. In the above-mentioned dialogue, the fourth meaning of putain used, which according to the monolingual French dictionary (see below), expresses anger, then astonishment. In general, there are four meanings of the word putain (Le Nouveau Petit Robert, 2012, 1624):

1) Pej.vulg. a prostitute

2) Pej.vulg. a woman practising a free sexual life

3) Colloquial. a person who would like to be popular with everybody

4) Interjection. colloquial. Putain! it expresses astonishment, anger, etc... putain de (et subst.), expresses contempt, despair.

When analysing the translations of students studying translation and interpreting we discovered the following results. The expressions in the brackets show a verbatim translation into French so that we might point out difficulties in translation as well as mistakes of the students. The first example of the word putain occurs 6 times. The

XLinguae Journal, Volume 10 Issue 3, June 2017, ISSN 1337-8384 
first word putain was translated by the students as hajzlíci! (assholes!) [emmerdeurs], the second word translated as the interjection tsss!, the third occurrence of the word omitted intentionally, the fourth occurrence translated as a vulgarism do riti!(fuck off!) [au cul, dans le cul], the fifth occurrence also translated by a vulgarism do riti! (shit!)[au cul], the sixth occurrence translated by the interjection hej! (hey!)

As we can see there is a wide range of equivalents. After critical analysis we find out that the first use of the word putain can be replaced with a less vulgar collocation do hája (get stuffed!) [dans le bois] and the fourth occurrence with a similar expression, the less vulgar do čerta [goddamn], the fifth occurrence with another synonym do psej matere (shit)[ à la mère de chien], which is more appropriate for someone who is more sensitive to vulgarisms. However, the vulgar expression do riti! (fuck off!) [au cul, dans le cul] is used too often by the translators of public Slovak television, either in dubbed French films, foreign films or in any other films. The repetition of the same vulgarism ten times or more has a disturbing effect on viewers. The translators could use a wide range of synonyms of the same expression with a lesser degree of vulgarity. It should be noted that the omission of the word putain (the third occurrence) in the translation of the above-mentioned dialogue into Slovak is fully justified; i.e. right. The vulgarism putain fulfils the function of interjection expressing anger (see the translation of the first example below)

Example No. 1 (translation into Slovak):

Kenz: Hej, aj ja chcem byt'v telke ako ty, hajzlíci![emmerdeurs] Ani o mne nerozprávajú, to myslia vážne, hm? Ani ma len nespomenú, ako by som ani neexistoval. Tsss! (interjection)

[Kenz: Aye, I would like be on TV like you assholes![emmerdeurs] They don't speak about me, are they serious, hm? They don't even mention me as if I don't exist. Tsss! (interjection)]

Redakt. TV: ...svedčí o tom, že bol terčom vybavovania účtov. Zatial' tol'ko informácií Kenz: Aaa, vieš čo, ja sám za nimi pôjdem! Ja im dám. XXX Vypni ten posratý televizor [télé de merde]. Do riti! [Au cul, dans le cul] Ja pôjdem za nimi, sám, a poviem im, uvidís. Poviem im, že ty si tu, že si so mnou a uvidíš, že aj ja budem v telke...

Ooo, čo sa ti stalo? Do riti! [Au cul, dans le cul] Čo ja s ním teraz? Oo! Hm! Oh! Hej!

\section{(interjection)}

[TV announcer: ...it proves that he was a target for settling past accounts. That is all, stay with us.

Kenz: A-aaa! You know what, I will probably go myself! I'll show them what is what. XXX Switch off that damned TV [télé de merde]. Shit! [Au cul, dans le cul] I'll go myself, and I'll tell them, you will see I'll tell them you are with me, and you'll see that I'll be on TV, too.

Oh, what happened? Shit! [Au cul, dans le cul] What to do with him now? Oh! Ahem! Oh! Aye!

(interjection)]

Example No. 2:

In the next example, we can also find a vulgar phraseme (vulgar collocation), couper les couilles, which can be translated into Slovak with several equivalents.

Tony : Bravo, le professionnel! Ça fait 3/4 d'heure qu'on t'attend. Bon, tu les as, les cagoules? 
Moussa: Tiens, fais gaffe, c'est à ma soeur. Si elle voit que j'ai pris ses collants, elle va

me couper les couilles!

Tony: Des cagoules j'avais dit! Putain des cagoules

Example No. 2 (translation into Slovak) :

Tony: Bravo, ty profesionál! Už tu tvrdneme trištvrte hodiny. Doniesol si tie kukly?

Moussa : Na. Ale dávaj bacha, sú sestrine. Ked'zistí, že som jej zobral silonky, urve mi gule/odreže mi semenníky/vykastruje ma [elle m'arrache les couilles/elle me coupe les couilles/elle va me castrer]

Tony: Kukly, povedal som kukly, ty dutá hlava! [tête vide] - incorrect translation

Tony: Kukly, povedal som Kukly, sprosté kukly[bêtes cagoules] - correct translation

[Tony : Bravo, you professional! We have been here more than three quarters of an hour. Have you brought the masks?

Moussa: Here they are. But be careful, they belong to my sister. If she finds out that I took her nylons, she will cut my balls /cut my testicles/castrate me [elle m'arrache les couilles/elle me coupe les couilles/elle va me castrer]

Tony: Masks, I said masks, you empty vessel! [tête vide] - incorrect translation

Tony: Masks, I said masks, damned masks [bêtes cagoules] - correct translation]

The vulgar phraseme (idiom) in Slovak urvat' gule niekomu (cut somebody's testicles)[arracher les couilles à qqn d'une façon violente/castrer qqn] mostly corresponds with the French vulgar phraseme couper les couilles à qqn. This vulgar expression is not frequently used in Slovak. It is a variant of the phraseme casser les pieds à qqn, which is not so vulgar. The vulgar variant casser les couilles à qqn can be replaced by the less vulgar synonym les casser à qqn. The vulgar noun was replaced by the pronoun, which is typical of French. Slovak does not have such a substitution in writing. However, it is possible at the colloquial level.

We also noticed that the translation of the expression putain des cagoules caused many problems for students due to the lack of knowledge or experience. According to the dictionary Le dictionnaire de l'argot $(2010,657)$ un or une putain de... is a formulation which either expresses contempt or simply impatience or a bad mood. This is exactly the case of this collocation putain des cagoules. In France, the TV series Les beaux mecs was not allowed for children younger than 10 years, in the Unites States of America for children and teenagers younger than 17 years. One of the reasons could be the higher/excessive occurrence of the vulgarisms.

In their commentaries, the students explain that there exist several translation approaches:

1) the film is not allowed for children younger than 15 years: certain vulgarisms are possible;

2) the film is not allowed for children younger than 10 years: the use of vulgarism is forbidden;

3) The opinion of others is different. If the dialogues of the original film comprise vulgarisms, the translator will not omit them and thus the spirit of the social environment is preserved.

This last group of translators does not take into account the audience and lumps adults, teenagers and children together. It was not an easy task to explain to them that the television as a public institution is concerned, and the impact on the viewers is the same regardless whether it is a public or private institution. Thus, it is clear that

XLinguae Journal, Volume 10 Issue 3, June 2017, ISSN 1337-8384 
translators have some power in their hands and they can influence the degree of vulgarity in a specific translation. Their power can influence the language level of dialogue, to soften the language of characters to some extent and at the same time maintain the rough and vulgar discourse of characters. Each of the vulgar expressions has its variants, synonyms, which expresses the spirit of discourse in a specific social environment. B. Hochel (1988: 186) also mentions that vulgarity can be modified, softening depending on the context, situation and person speaking.

There is another problem in the translation process. Translators are often criticised for markedly being influenced by the source language. In this case a translation does not sound natural, but artificial (T. Hrehovčík, 2006: 31). It is typical of translators beginners with a lack of translation experience. In our opinion there is a way how to enhance the quality of a translation and thus achieve a desirable effect: the mastering of the source language and target language as much as possible, and to differentiate the degrees of vulgarity of a relevant discourse. It is a lengthy process that cannot be mastered overnight.

Example No. 3: it points out the frequent use of the word putain:

Dialo: $J$ ' vais $t^{\prime}$ la faire boire ta putain d 'piss!

Ahhh!

Kenz: Dialo putain! Dialo putain! Dialo!

Putain d'sa mère! Eh Dialo! Eh Dialo! Putain, putain, putain! Dialo

Dialo Dialo! Dialo! Hé Mec! Eh tu veux qu'j'appelle ma soeur? Eh parle-moi

putain! Tu veux qu' j' appelle ma soeur? Eh Dialo putain! Dialo putain!

Dialo!

Example No. 4

Tony: Je change les plans parce qu' avec ta voiture de merde, on peut pas s'garer devant l' café. Abruti

Example No. 4 (translation into Slovak)

Tony: Zmena plánu, pretože s tvojím posratým autom sa nedá pred kaviarňou zaparkovat'. Idiot.

[Tony: I have changed our plan because it is not possible to park with your damned car in front of the café. Idiot! ]

This example shows that it is possible to replace the vulgarism voiture de merde = posraté auto (fucking car) [voiture chiante] with the less vulgar synonym poondiate auto (damned car). This synonym is a colloquial form of the used vulgarism, which is not so coarse.

Example No. 5 points out the many possibilities at the disposal of translators, who can select the most suitable equivalents in a sensitive way.

Kenz : Fais gaffe à qui? À Dialo?Écoute bien. Dialo, $\boldsymbol{j}^{\prime}$ l'emmerde! = mám ho na háku (I don't care), mám ho v paži (I thumb my nose at him) (je l'ai sur un crochet/ sous l'aisselle]

Emmerder qqn = tenir quelqu'un pour inexistant, pour insignifiant = mat' niekoho na háku,

mat' ho v paži (I don't care, I thumb my nose at him)) [avoir qqn sur un crochet/sous l'aisselle]. There is also a vulgar variant = bozat' niekoho $v$ rit' (sod him) [baiser qqn dans le cul], which is better to avoid.

There is also another issue. Students prefer a more vulgar synonym, and they do not want to use other possibilities; i.e. less vulgar synonyms. They argue that everything is vulgar today, the use of vulgar words is normal and therefore it is not possible to 
soften this type of lexis. However, they are wrong. First of all, they do not know how to use this vulgar verb or vulgarisms in general. P. Guiraud (1991: 33) claims that these words or expression cannot be understood as an outright obscenity, and particularly because they lose its motivation; i.e. they are unmotivated. In the minds of those who use them, they do not evoke the notion of primary meaning. Here it refers to the negation of this value. The author also notes that (1991: 119) that every swearword is a manifestation of insecurity, anxiety, the feeling of inferiority, obscured by words.

In our opinion, the focus should be on viewers, and one should try to express oneself with the most suitable lexis, and not to escalate vulgarity. V. Patráš (1997) mentions that little attention was devoted to the issue of obscene elements, means and procedures in Slovak linguistics, not speaking about mass media. We should not forget children and the young generation, because we are responsible for them; we influence them either positively or negatively. Furthermore, translators should respect the language norm. They influence the development of the language norm and bear the responsibility for it (S. Ondrejovič, 2006: 35).

\section{Language and Culture}

Translations of literary, audio and audiovisual works, specifically the translations of foreign films markedly contribute to the globalisation of a lifestyle and a way of thinking because they open the door to a better understanding of foreign cultures. However, it is necessary to adapt the translation of the source language to the culture of the viewers of the target language as much as possible. According to the research of F. Schmitt (2014: 340), French and Slovak television are still subject to national specific features, despite the fact that this type of media is often considered a factor of culture's uniformity. In this context it should be noted that the increasing vulgarity in mass media manifests the uniformity of culture as well as the specific features of certain cultural context.

Translators confronted with the problem of translating vulgar words must take into account not only the cultural aspect of the source text, but must also know the specific features of the target language (V. Bíloveský, 2011: 13, 33; A. Schneiderová, 2012: 73; A. Zelenková, 2015, 46). As every language is closely interconnected with the culture representatives, P. Mogorrón Huerta $(2012$ : 83, 85) points out that the work of a translator cannot be limited to the usual comparison of language structures and does not take into account cultural contents, style, and so on. Though, it is not always easy to understand expressions with a cultural context and with references specific for a relevant community and its culture (V. Patráš, 1998: 118). J. Birová (2013, 96) underlines that every culture dispose of so-called implicit cultural contents deeply hidden in culture and social interactions. P. Poliak (2015: 21) points out that the dynamic character of every culture has been developing in context with other cultures. They are just the specific features of individual cultures, which create problems for translators, and vulgarisms represent such a specific feature.

We agree with the opinion of S. Ondrejovič (2006: 41), that vulgarisms, whether we like or not are part and parcel of our lives whether we use them or not. Vulgar lexis in translation should be treated with caution. It may happen that a translator is not able to estimate the intensity of a relevant vulgar expression and selects an inadequate equivalent. He often decides on the most vulgar variant, which sounds unnatural in target language. We agree with J. Klincková (2010) that lexis is the most dynamic stratum of language and it reflects the social changes and needs of its users. The perception of the vulgarity of a specific word or expression has been changing after some time. 


\section{Conclusion}

Is there any way to protect the language in film dialogue in mass media from exaggerated and inadequately translated vulgarisms? On one hand, university teachers should teach future translators that language norm should be respected. On the other hand, television and radio as public institutions should devote their attention to the quality of the translation, and translators influence it significantly. Translators play an important role in the transfer of language and its cultural aspect, including all its nuances. Currently, mass media markedly influences the development of a value system. Viewers, readers, Internet users not always aware of how often they face translations which are the products of culture (dubbed films in our case). Therefore, the work of the translator is significant. On one hand, translators can shift the dialogue text to a more intensive level of vulgarity, and on the other they can soften vulgar expressions. Viewers and specifically the younger generation should be offered translations which treat colloquial and specifically vulgar language level sensitively, but at the same time, the quality of the translation should be preserved.

\section{Bibliographic references}

BILOVESKY, V. 2011. Zazraky v orechovej skrupinke. Banska Bystrica: Univerzita Mateja Bela, Fakulta humanitných vied. ISBN 978-80-557-0249-0

BIROVA, J. 2013. About theoretical definitions of pluralistic and Pluricultural approaches. In: XLinguae. Vol. 6, no. 2 (2013), p. 91-103. ISSN 1337-8384.

COHEN,F.2013.Lemétierde"sous-titreuse".In: http://www.bifi.fr/public/ap/article.Php ?id (15.12.2015).

LAPLACE, C. - LEDERER, M. - GILE, D. (eds.). 2009. La traduction et ses métiers. Aspects théoriques et pratiques. Cahiers Champollion, 12,73-86 Caen: Lettres Modernes

Minard. http://cirinandgile.com/DGCVEN.htm 20.01.2016

COHEN, J. 2011. http://www.buzzmoica.fr/video/putain-le-mot-francais-magiquepour-lesamericains-27775 30.1.2015

COLIN, J.-P. - MEVEL, J.-P. - Leclère, CH. 2010. Le dictionnaire de l'argot et du français populaire. Paris : Larousse. ISBN-10: 2035852994

FRANÇOIS-GEIGER, D.1991. Panorama des argots contemporains. In : D. FrançoisGeiger, \& J.-P. Goudaillier (eds.), Langue française 90, Parlures argotiques, pp. 5-9. Paris : Larousse.

GROMOVA, E. - MUGLOVA, D. 2005. Kultúra - Interkulturalita - Translácia. Nitra : Univerzita Konštantína Filozofa, Filozofická fakulta. ISBN 80-8050-946-8

GUIRAUD, P. 1991. Les gros mots. Paris : Presses Universitaires de France. ISBN 978-2130477983

HOCHEL, B. 1988. Tabuizované slová v slovenčine. In: Studia Academica Slovaca. 17. Red. J. Mistrík, pp.179-187, Bratislava.

HOCHEL, B. 1990. Preklad literárneho diela. In : Acta Universitatis Carolinae Philologica n. 2-3, pp. 213-221. Praha : Univerzita Karlova.

HOCHEL, B. 1993. Slovník slovenského slangu. Bratislava : Hevi. ISBN 80-8551805-8

HREHOVCIK, T. 2006. Prekladatel'ské minimum. Bratislava : Iris. ISBN 80-89256023

KLINCKOVA, J., 2010. Konkurencia a kooperácia lexikálnych prostriedkov v profesijnej komunikácii. Bratislava : Veda. ISBN-10: 9788022411073

MESKOVA, L. 1999. Frazeologické jednotky s vulgárnou konotaciou. In: 15 x o prekladu, pp. 40-42. Praha : JPT.

MOGORRON HUERTA, P. 2012. La traduction des unités phraséologiques à contenu culturel. In: Rencontres Méditerranéennes n. 4, pp. 81-95. Langues spécialisées, 
figement et traduction. Mogorrón Huerta, P., - Mejri, S. (eds.). Alicante : Quinta Impresión, S. L. ISBN : 978-84-9717-209-7

ONDREJOVIC, S. 2006. Ked cielovym jazykom je slovencina. In: Letna skola prekladu n. 4, pp. 33- 45. Medzikulturny a medzipriestorovy faktor v preklade. Bratislava : AnaPress. ISBN 80-89137

PATRAS, V. 2012. Sociolingvisticke vyskumy bezprostrednej komunikacie a dynamika pojmu ustnost. In: Języki słowiańskie $w$ ujęciu socjolingwistycznym, pp.171-182. Prace

przygotowane na XV Międzynarodowy Kongres Slawistów, Mińsk 2013. Biblioteka „LingVariów”, T. 15. Red. H. Kurek. Kraków : Uniwersytet Jagielloński - Wydział Polonistyki. ISBN 978-83-7638-237-1

PATRAS, V. 2010. Hovorena podoba jazyka v meste ako metodologicky odkaz a vzzva. In: Odkazy a vyzvy modernej jazykovej komunikacie, pp. $138-150$. Zborník prispevkov zo 7. medzinarodnej vedeckej konferencie konanej 23. - 24. 09. $2009 \mathrm{v}$ Banskej Bystrici, J. Klinckova, (ed). Banska Bystrica, Slovakia: Univerzita Mateja Bela. ISBN 978-80- 8083-1992, 81

PATRAS, V. 1998. Vulgarizmy v postmodernom case (slovensko-polske lexikograficke paralely). In: Słowo i czas, pp. 116 - 123. Red. S. Gajda - A. Pietryga. Opole : Uniwersytet Opolski.

PATRAS, V. 1997. Obscennost a jej sociolingvistické parametre (Na fragmentoch slovenskej prozy 90. rokov). In: Studia Academica Slovaca. 26. Prednásky XXXIII. letneho seminara slovenskeho jazyka a kultury. Red. J. Mlacek. Bratislava, Stimul Centrum informatiky a vzdelavania FF UK 1997, pp. 127 - 136.

POLIAK, P. 2015. Interkulturne rozdiely v manazmente organizacii. Banska Bystrica : Belianum. ISBN 978-80-557-1029-7

RAKSANYOVA, J. 2006. Preklad v kulture a kultura v preklade. In: Letna skola prekladu 4, pp. 9-20. Medzikulturny a medzipriestorovy faktor v preklade. Bratislava: AnaPress. ISBN 80-89137

SCHMITT, F. 2014. Comparaison interculturelle de journaux télévisés français et slovaques.

In : Lingua, cultura e media, pp. 333-353. Roma, : Aracne editrice. ISBN : 978-88548-511-5

SCHNEIDEROVA, A. 2012. SKOPOS Theory in the translation process. In: Journal of Modern Science, n. 2/13, pp. 71-76. ISSN 1734-2031

ZELENKOVA, A. 2015. Specifika odbornej anglictiny a rozvijanie interkulturnej kompetencie. Particularities of English for specific purposes and development of intercultural competence In: XLinguae : European scientific language journal. Vol. 8, no. 1 (2015), pp. 36-49. ISSN 1337-8384

Words: 4885

Characters: 30432 (16.9 standard pages)

assoc. prof. dr. L’udmila Mešková, PhD.

Department of European Cultural Studies, Faculty of Arts

Matej Bel University in Banská Bystrica

Tajovského 40, 97401 Banská Bystrica

Slovakia

ludmila.meskova@umb.sk 